\title{
GAMBARAN FAKTOR-FAKTOR RISIKO KEJADIAN PREEKLAMPSIA \\ PADA IBU BERSALIN DENGAN PREEKLAMPSIA \\ (Di RS Aura Syifa Kabupaten Kediri bulan Februari - April tahun 2016)
}

\author{
Widya Kusumawati, Aida Ratna Wijayanti, Wahyuningtyas ${ }^{1}$ \\ ${ }^{1}$ Akademi Kebidanan Dharma Husada Kediri Jawa Timur
}

\begin{abstract}
Abstrak
Preeklampsia merupakan sekumpulan gejala yang muncul selama kehamilan dengan usia lebih dari 20 minggu dengan tanda-tanda hipertensi, oedema, dan proteinuria. Penyebab preeklampsia belum diketahui, dan masih merupakan disease of theory. Tujuan penelitian untuk mengetahui faktor-faktor risiko kejadian preeklampsia pada ibu bersalin.

Desain penelitian adalah deskriptif, populasi semua ibu bersalin dengan preeklampsia sebanyak 43 ibu bersalin, menggunakan teknik total sampling, variabel dalam penelitian ini variabel tunggal yaitu faktor-faktor risiko kejadian preeklampsia pada ibu bersalin dengan preeklampsia. Pengumpulan data menggunakan rekam medik pada bulan Februari - April 2016, pengolahan data dengan menggunakan editing, coding, scoring, dan tabulating, kemudian data dianalisa menggunakan prosentase.

Hasil penelitian menunjukkan bahwa faktor-faktor risiko kejadian preeklampsia pada ibu bersalin dengan preeklampsia berdasarkan jumlah paritas (primigravida sejumlah $19 \%$, multigravida $81 \%$ ), usia $(<20$ sejumlah 7\%, 20-35 sejumlah 56\%, > 35 sejumlah $37 \%$ ), faktor lain (distensia rahim berlebihan sejumlah $17 \%$, hipertensi kronis sejumlah $2 \%$, riwayat preeklampsia sejumlah $14 \%$, dan tidak ada faktor sejumlah $67 \%$ ).

Kesimpulan dari hasil penelitian ini faktor-faktor risiko kejadian preeklampsia pada ibu bersalin dengan preeklampsia berdasarkan paritas tertinggi multigravida, usia tertinggi pada rentang 20-35 tahun, dan faktor lain karena distensia rahim berlebihan, hipertensi kronis serta riwayat preeklampsia.

Risiko preeklampsia pada ibu bersalin dari berbagai faktor tersebut dapat dijadikan gambaran oleh tenaga kesehatan untuk memberikan informasi kepada ibu-ibu hamil dan lebih mengutamakan pada antenatal care sedini mungkin untuk mendeteksi preeklampsia.
\end{abstract}

Kata kunci : Faktor Risiko Kejadian Preeklampsia.

Korespondensi : Jl. Ahmad Dahlan Gg II No 14 Mojoroto Kediri Jawa Timur HP : 085722223910, email : widya.koesoemawati@gmail.com

139 | Jurnal Kebidanan Dharma Husada Vol. 6, No. 2 Oktober 2017 


\section{Pendahuluan}

Rasio kematian maternal merupakan salah satu indikator MDG's (Millenium Developmen Goals) Indonesia pada tahun 2015 adalah 102 per kelahiran hidup. Berdasarkan Survey SDKI 2012 diketahui bahwa angka kematian ibu masih tinggi yaitu 359 / 100.000 kelahiran hidup, sehingga diketahui bahwa target MDG's 2015 masih belum tercapai. Maka dari pada itu tujuan pembangunan berkelanjutan program MDG's dilanjutkan ke SDG's (Sustainable Development Goals) dengan target angka kematian ibu adalah 70 per 100.000 kelahiran hidup pada tahun 2030 (Kemenkes RI, 2015).

Preeklampsia merupakan sekumpulan gejala yang secara spesifik hanya muncul selama kehamilan dengan usia lebih dari 20 minggu disini. Saat ini edema tidak lagi dijadikan komponen ketiga dari trilogi preeklamsia (Varney,2007:644). Faktor yang menyebabkan preeklamsia sampai saat ini masih belum diketahui penyebabnya, namun beberapa teori yang dapat menjelaskan penyebab preeklamsia yaitu ada beberapa teori mencoba menjelaskan perkiraan etiologi kelainan seperti pembengkakan-proteinuria-tekanan darah tinggi, sehingga kelainan ini sering dikenal sebagai the diseases of theory. Adapun teri-teori tersebut yaitu peran prostasiklin dan tromboksan, peran faktor immunologis, dan peran faktor genetik (Lubis, NL, 2013: 46-47).

Sedangkan beberapa faktor risiko pada kejadian preeklampsia yaitu sekitar $85 \%$ preeklamsia terjadi pada primigravida, grandemultidravida, janin besar, distensia rahim berlebihan (hidramnion, hamil ganda mola, molahidatisoda) sekitar $14 \%$ sampai $20 \%$, diabetus melitus, hipertensi mencapai $25 \%$ dan usia ibu diatas 35 tahun (Radjamuda, N, Et al, 2014).

Dampak preeklampsia pada ibu yaitu kelahiran prematur, oliguria, kematian, sedangkan dampak pada janin yaitu pertumbuhan janin terhambat, oligohidramnion, dapat pula meningkatkan morbiditas dan mortalitas (Yogi ED etal,2014).
Pencegahan pre-eklamsia/eklamsia sangat penting agar tidak terjadi bahaya pada ibu dan janinnya. Ibu hamil harus periksa antenatal yang teratur dan bermutu secara teliti, mengenali tanda-tanda sedini mungkin (pre-eklamsia ringan), memberikan pengobatan yang cukup supaya penyakit tidak menjadi lebih berat, harus selalu waspada terhadap kemungkinan terjadinya pre-eklamsia kalau ada faktor-faktor presdiposisi, memberikan penerangan tentang manfaat istirahat dan tidur, ketenangan, serta pentingnya mengatur diit rendah garam, lemak, serta karbohidrat dan tinggi protein, juga menjaga kenaikan berat badan yang berlebihan. (Padila,2015:150).

Dari hasil study pendahuluan di RS Aura Syifa Kabupaten Kediri bulan Februari tahun 2016 terdapat jumlah persalinan sebanyak 118 ibu bersalin yang menderita preeklampsia sebanyak 7 orang. Oleh karena itu peneliti tertarik meneliti mengenai "Faktor-faktor Risiko Kejadian Preeklampsia Pada Ibu Bersalin Dengan Preeklampsia di RS Aura Syifa Kabupaten Kediri."

\section{Metode}

Desain penelitian pada penelitian ini adalah diskriptif. Populasi adalah semua ibu bersalin dengan preeklampsia sebanyak 43 ibu bersalin di RS Aura Syifa Kabupaten Kediri, menggunakan teknik total sampling. Variabel dalam penelitian ini adalah variabel tunggal yaitu faktor-faktor risiko kejadian preeklampsia pada ibu bersalin dengan preeklampsia. Pengumpulan data menggunakan rekam medik pada bulan Februari - April 2016. 
Widya Kusumawati : Faktor-Faktor Risiko Kejadian Preeklampsia Pada Ibu Bersalin (Di RS Aura Syifa Kabupaten Kediri Bulan Februari - April Tahun 2016)

Hasil

Tabel 1. Distribusi Ibu Bersalin Dengan Preeklampsia Berdasarkan Pekerjaan Di RS Aura Syifa Kabupaten Kediri Bulan Februari-April Tahun 2016

\begin{tabular}{llcc}
\hline No. & JenisPekerjaan & Jumlah & Prosentase(\%) \\
\hline 1 & IRT & 25 & 58 \\
\hline 2 & Tani & 2 & 5 \\
\hline 3 & Swasta & 13 & 30 \\
\hline 4 & PNS & 2 & 5 \\
\hline 5 & Wiraswasta & 1 & 2 \\
\hline & Jumlah & 43 & 100 \\
\hline
\end{tabular}

Pada tabel 1 di atas menunjukkan bahwa dari 43 ibu bersalin dengan preeklampsia, pekerjaan tertinggi yaitu

sebagai ibu rumah tangga sebanyak 25 orang

$(58 \%)$.

Tabel 2. Distribusi Ibu Bersalin Dengan Preeklampsia Berdasarkan Pendidikan Di RS Aura Syifa Kabupaten Kediri Bulan Februari-April Tahun 2016

\begin{tabular}{lccc}
\hline No. & Pendidikan & Jumlah & Prosentase(\%) \\
\hline 1 & SD & 3 & 7 \\
\hline 2 & SMP & 19 & 44 \\
\hline 3 & SMA & 16 & 37 \\
\hline 4 & PT & 5 & 12 \\
\hline & Jumlah & 43 & 100 \\
\hline
\end{tabular}

Pada tabel 2 di atas menunjukkan bahwa dari 43 ibu bersalin dengan preeklampsia di dapatkan hasil tertinggi yaitu pendidikan SMP dengan jumlah 19 orang $(44 \%)$.

Tabel 3. Distribusi faktor risiko kejadian preeklampsia pada ibu bersalin dengan preeklampsia berdasarkan jumlah paritas di RS Aura Syifa Kabupaten Kediri bulan Februari - April Tahun 2016

\begin{tabular}{llcc}
\hline No & \multicolumn{1}{c}{ Paritas } & Jumlah & Prosentase (\%) \\
\hline 1. & Primigravida & 8 & 19 \\
\hline 2. & Multigravida & 35 & 81 \\
\hline 3. & Grandemultigravida & 0 & 0 \\
\hline & Jumlah total & 43 & $100 \%$ \\
\hline
\end{tabular}

Pada tabel 3 di atas menunjukkan bahwa dari 43 ibu bersalin dengan preeklampsia, berdasarkan jumlah paritas didapatkan hasil tertinggi yaitu multigravida sebanyak 35 orang $(81 \%)$. 
Tabel 4. Distribusi faktor risiko kejadian preeklampsia pada ibu bersalin dengan preeklampsia berdasarkan usia di RSAura Syifa Kabupaten Kediri bulan Februari - April Tahun 2016

\begin{tabular}{llccc}
\hline No & & Usia & Jumlah & Prosentase (\%) \\
\hline 1. & $<20$ & 3 & 7 \\
\hline 2. & $20-35$ & 24 & 56 \\
\hline 3. & $>35$ & 16 & 37 \\
\hline & Jumlah total & 43 & $100 \%$ \\
\hline
\end{tabular}

Pada tabel 4 di atas menunjukkan bahwa dari 43 orang ibu bersalin dengan preeklampsia, berdasarkan usia didapatkan hasil tertinggi yaitu umur 20-35 tahun sebanyak 24 orang $(56 \%)$.

Tabel 5. Distribusi faktor risiko kejadian preeklampsia pada ibu bersalin dengan preeklampsia berdasarkan faktor lain di RS Aura Syifa Kabupaten Kediri bulan Februari - April Tahun 2016

\begin{tabular}{llcc}
\hline No. & Faktor lain & Jumlah & Prosentase (\%) \\
\hline 1. & Distensia rahim berlebihan & 7 & 17 \\
\hline 2. & DM & 0 & 0 \\
\hline 3. & Hipertensi kronis & 1 & 2 \\
\hline 4. & Riwayat PE & 6 & 14 \\
\hline 5. & Tidak ada faktor & 29 & 67 \\
\hline & Jumlah total & 43 & 100 \\
\hline
\end{tabular}

Pada tabel 5 di atas menunjukkan bahwa dari 43 orang ibu bersalin dengan preeklampsia sejumlah 29 orang $(67 \%)$ tidak ada faktor risiko preeklampsia.

\section{Diskusi}

Paritas (primigravida, multigravida, grandemultigravida)

Dari hasil penelitian yang didapatkan pada tabel 3 bahwa dari 43 ibu bersalin yang mengalami preeklampsia, ibu primigravida sebanyak 8 orang (19\%), multigravida 35 orang $(81 \%)$, sedangkan yang berstatus grandemultigravida $(0 \%)$.

Secara teori, primigravida lebih beresiko untuk mengalami preeklampsia dari pada multigravida karena preeklampsia biasanya timbul pada wanita yang pertama kali terpapar vilus korion. Hal ini terjadi karena pada wanita tersebut terjadi mekanis imunologik pembentukan blocking antibody yang dilakukan oleh HLA-G (Human Leucocyte Antigen G) terhadap antigen plasenta belum terbentuk secara sempurna, sehingga proses implantasi trofoblas ke jaringan desidual ibu menjadi terganggu. Primigravida juga rentan mengalami stres dalam menghadapi persalinan yang akan menstimulasi tubuh untuk mengeluarkan kortisol. Efek kortisol adalah untuk meningkatkan respon simpatis, sehingga curah jantung juga akan meningkat.

Penelitian ini menemukan proporsi penderita preeklampsia pada multigravida lebih tinggi dibandingkan dengan primigravida. Semua wanita memiliki resiko mengalami preeklampsia selama hamil, bersalin dan nifas. Preeklampsia tidak hanya terjadi pada primigravida / primipara, pada multigravida yang mengalami peregangan rahim yang berlebihan dapat menyebabkan iskemia berlebihan yang dapat menyebabkan preeklampsia (Suwanti, dkk, 2012).

Dari hasil penelitian di RS Aura Syifa Kabupaten Kediri tahun bulan Februari - April 2016, tidak ditemukan faktor risiko pada grandemultigravida. Saat ini ibu yang berstatus grandemultigravida sudah sangat jarang bahkan sudah hampir tidak ada atau tidak ditemukan ibu grandemultigravida. Hal ini dikarenakan saat ini untuk mengakses sumber informasi sangatlah mudah dibandingkan di masa yang lampau serta 
terjadi pergeseran paradigma dimana jumlah anak saat ini menjadi pertimbangan dalam hal ekonomi keluarga. Orang-orang dulu berpendapat jika mereka mempunyai anak banyak rejeki mereka semakin banyak juga. Sedangkankan saat ini justru kebalikannya jika mereka mempunyai anak banyak tanggung jawab serta kebutuhan mereka juga semakin banyak. Sehingga saat ini jarang ditemukan ibu grandemultigravida. Namun grandemultigravida tetap menjadi faktor risiko kejadian preeklampsia pada ibu bersalin, karena ibu yang melahirkan lebih dari 4 kali sangat berisiko pada ibu dan juga bayinya. Saat ini ibu grandemultigravida bergeser pada multigravida. Karena saat ini sudah di adakan program KB, sehingga jarang ibu bersalin yang lebih dari 4 kali.

\section{Usia}

Dari hasil penelitian yang diperoleh melalui rekam medik pada tabel 4 bahwa dari 43 orang ibu bersalin dengan preeklampsia, usia $<20$ sebanyak 3 orang (7\%), 20-35 sebanyak 24 $(56 \%),>35$ sebanyak 16 orang $(37 \%)$.

Usia mempunyai pengaruh terhadap kehamilan dan persalinan ibu. Usia yang kemungkinan tidak risiko tinggi pada saat kehamilan dan persalinan yaitu umur 30-35 tahun, karena pada usia tersebut rahim sudah siap menerima kehamilan, mental sudah matang dan sudah mampu merawat bayi dan dirinya. Sedangkan umur kurang dari 20 tahun dan lebih 35 tahun merupakan umur yang risiko tinggi terhadap kehamilan dan persalinan. Dengan demikian diketahui bahwa umur ibu pada saat melahirkan turut berpengaruh pada morbiditas dan mortalitas ibu maupun anak yang dilahirkan.

Usia aman untuk kehamilan dan persalinan adalah 20-35 tahun. Wanita usia $>35$ tahun mempunyai risiko untuk menderita hipertensi kronik yang akan berlanjut menjadi superimposed preeclamsia ketika sedang hamil (Prahastiwi, 2008).

Berdasarkan penelitian di RS Aura Syifa Kabupaten Kediri bulan Februari - April tahun 2016 di temukan ibu yang berusia lebih dari 35 tahun sebanyak 16 orang (37\%). Pada penelitian ini ibu berusia lebih 35 tahun tidak sebanyak pada ibu yang berusia 20-35 tahun, dikarenakan saat ini kebanyakan ibu yang hamil berusia 20-35 tahun. Mereka sudah mengetahui jika ibu yang sedang sedang hamil dengan status usianya tua itu beresiko pada dirinya sendiri dan juga pada janin atau bayinya. Namun ibu yang berusia lebih dari 35 tahun tetap harus diwaspadai, karena kondisi fisik ibu hamil dengan usia lebih dari 35 tahun akan sangat menentukan proses kelahirannya, hal ini pun turut mempengaruhi kondisi janin, kontraksi uterus juga sangat di pengaruhi oleh kondisi fisik ibu. Kondisi ibu yang hamil pada umur lebih dari 35 tahun akan mengalami banyak kesulitan karena pada usia tersebut mudah terjadi penyakit pada ibu dan karena organ kandungan menua jalan lahir juga tambah kaku sehingga terjadi persalinan macet dan perdarahan. Disamping hal tersebut kemungkinan mendapatkan anak cacat juga menjadi lebih besar. Oleh karena itu sebagai tenaga kesehatan memberikan pengetahuan kepada ibu-ibu tentang bahaya dan resiko dari hamil dengan usia tua.

\section{Faktor Lain}

Distensia rahim berlebihan : hidramnion, hamil ganda, mola hidatidosa, dan janin besar

Berdasarkan penelitian pada tabel 5 diperoleh bahwa dari 43 ibu bersalin dengan preeklampsia yaitu hidramnion sebanyak 1 orang $(2 \%)$, hamil ganda sebanyak 1 orang $(2 \%)$, mola hidatidosa tidak ada $(0 \%)$ sedangkan untuk janin besar yang mengalami preeklampsia sebanyak 5 orang $(12 \%)$.

Menurut (Norma, ND, 2013 : 59) preeklampsia terjadi pada $14 \%$ sampai $20 \%$ kehamilan dengan janin lebih dari satu . Penyakit preeklampsi yang meliputi : nuliparitas, penyakit trofoblastik $(70 \%$ terjadi pada kasus mola hidatidosa), janin besar, kehamilan kembar tanpa memperhatikan paritas (Varney, 2007: 646). Komplikasi hamil ganda pada trimester kedua / ketiga meliputi persalinan prematuritas, kehamilan dengan hidramnion, preeklampsia / eklampsia, kelainan letak, perdarahan antepartum / plasenta previa / solusio plasenta, gangguan pertumbuhan janin (IUGR, pertumbuhan 
prematuritas, terjadi anomali pertumbuhan). (Manuaba : 2008 : 107).

Menurut teori diatas dijelaskan bahwa penyakit mola hidatidosa $70 \%$ merupakan faktor risiko preeklampsia. Namun pada penelitian di RS Aura Syifa Kabupaten Kediri pada bulan Februari - Apri tahun2016 tidak ditemukan pada mola hidatidosa. Sedangkan mayoritas preeklampsia terjadi pada janin besar sebanyak 5 orang (12\%). Ibu yang makannya banyak bisa menyebabkan janin besar, sehingga janin besar merupakan faktor risiko terjadinya preeklampsia. Namun pada hidramnion dan hamil ganda masing-masing 1 orang $(2 \%)$. Namun molahidatidosa tetap menjadi faktor risiko kejadian preeklampsia pada ibu bersalin walaupun pada penelitian ini tidak ditemukan kasus pada molahidatidosa. Karena molahidatidosa juga merupakan faktor yang berisiko pada bayi. Sehingga kasus molahidatidosa juga harus diwaspadai.

Dalam penelitian ini peneliti menyimpulkan bahwa hidramnion, hamil ganda, mola hidatidosa, dan janin besar tetap menjadi faktor risiko terjadinya preeklampsia. Karena ke empat faktor tersebut juga berbahaya bagi ibu dan juga harus di perhatikan.

\section{Diabetus Mellitus}

Berdasarkan penelitian diperoleh melalui rekam medik didapatkan, pada tabel 5 bahwa dari 43 bersalin dengan preeklampsia, tidak ada yang menderita DM.

Diabetus melitus merupakan kelainan herediter dengan ciri influensi atau absesnya insulin dalam sirkulasi darah, konsentrasi gula darah tinggi, dan berkurangnya glikogenesis.

Diabetus mellitus dalam kehamilan menimbulkan banyak kesulitan, karena penyakit ini akan banyak menimbulkan perunahanperubahan metabolik dan hormonal pada penderita yang juga dipengaruhi kehamilan, sebaliknya juga diabetes akan mempengaruhi kehamilan dengan frekuensi 0,3-0,7\%

Menurut (Salwa, R, 2016) wanita dengan riwayat diabetes yang memiliki protein dalam urin mereka sebagai akibat dari komplikasi nefropati diabetik (penyakit ginjal) memiliki sekitar empat kali peningkatan risiko untuk mengembangkan pre-eklampsia.

Komplikasi pengaruh dalam kehamilan yaitu abortus, partus prematurus, pre eklamsia, hidramnion, kelinan letak janin, insufisiensi plasenta. Sedangkan pengaruh pada janin yaitu abortus, cacat bawaan, dismaturitas, janin besar, kematian dalam kehamilan, kematian neonatal, kelainan neurologi, kelainan psikologi kemudian hari, hipokalsemia, hiperbilirubimia. (Purwaningsing : 2010 : 135).

Pada penelitian di RS Aura Syifa Kabupaten Kediri bulan Februari-April Tahun 2016 tidak di temukan faktor risiko diabetus melitus. Namun diabetus tetap menjadi faktor risiko terjadinya preeklampsia karena diabetus melitus kadar glukosa meningkat, itu merupakan salah satu faktor menjadi preeklampsia. Serta ibu yang obesitas oleh faktor genetik, gangguan metabolik, dan konsumsi makanan yang berlebihan, makin gemuk seseorang makin banyak pula jumlah darah yang terdapat didalam tubuh yang berarti makin berat pula fungsi pemompaan jantung. Sehingga dapat menyumbangkan terjadinya preeklampsia. Sehingga hal ini perlu di waspadai.

\section{Hipertensi kronis}

Berdasarkan hasil penelitian yang diperoleh pada tabel 5 bahwa dari 43 ibu bersalin dengan preeklampsia pada ibu yang memiliki riwayat hipertensi kronis sebanyak 1 orang ( $2 \%$ ).

Hipertensi kronis yaitu jika muncul sebelum kehamilan atau pada usia kehamilan dibawah 20 minggu, tekanan darah sistolik $>140 \mathrm{mmHg}$ dan diastolik > $90 \mathrm{mmHg}$. Apabila hipertensi didiagnosa selama kehamilan, terapi tidak kunjung menurun hingga pasca partum. Hipertensi berlanjut berlanjut menjadi superimposed preeclamsia ketika sedang hamil. Pada ibu yang mengalami hipertensi kronis insiden dapat mencapai 25\%. Faktor risiko yang terkait dengan perkembangan hipertensi pada ibu hamil yaitu congenital, grandemultigravida, janin besar, kehamilan dengan janin besar, morbit obesitas. Sedangkan klasifikasinya yaitu hipertensi kronis, preeklampsia dan eklampsia, preekalmpsia pada hipertensi kronis, hipertensi transparan. Sedangkan menurut (Manuaba: 2010: 335) kehamilan dengan hipertensi dapat berlangsung sampai aterm tanpa gejala menjadi preeklampsia tidak murni. Hanya sekitar $20 \%$ dapat menjadi preeklampsia / eklampsia tidak murni (superimposed) yang disertai gejala proteinuria, edema, dan terdapat keluhan nyeri epigastrium, sakit kepala, penglihatan kabur, dan mual serta muntah.

Berdasarkan uraian diatas, dapat disimpulkan bahwa pada penelitian di RS Aura Syifa Jurnal Kebidanan Dharma Husada Vol. 6, No. 2 Oktober 2017| 144 
Kabupaten Kediri bulan Februari- April tahun 2016 ibu yang mempunyai hipertensi kronis sebanyak 1 orang. Hipertensi kronis tetap menjadi faktor risiko terjadinya preeklampsia. Karena ibu yang mengalami hipertensi kronis tekanan darahnya 140/90 $\mathrm{mmHg}$ dan itu bisa beralih ke preeklampsia. Ibu dengan hipertensi kronis sangat berbahaya karena besar kemungkinan beralih ke preeklampsia. Oleh karena itu di anjurkan ibu- ibu yang hamil untuk menjaga pola makan, menghindari makanan yang bisa menyebabkan naiknya tekanan darah.

Dalam usaha untuk menurunkan angka kesakitan dan kematian ibu (AKI) dan angka kematian anak (AKA), bidan memegang peranan yang penting melalui pelaksanaan pengawasan kehamilan. Salah satu yang harus diperhatikan saksama adalah tekanan darah yang seharusnya dalam batas normal. Bila dijumpai tekanan darah sekitar 140/90 mmHg sudah harus mendapat perhatian bidan untuk mengukur ulang dengan tenggang waktu 6 jam. Apabila dalam tenggang waktu 6 jam tekanan darah masih tetap, sebaiknya ibu hamil dikonsultasikan kepada dokter. Terdapat kemungkinan bahwa kehamilan yang disertai hipertensi sewaktu-waktu menjadi preeklampsia. Bidan dapat melakukan pengawasan hamil secara ketat sehingga jika ada perubahan harus segera melakukan konsultasi atau merujuk penderita kepusat pelayanan terpadu.

\section{Riwayat Preeklampsia}

Dari hasil penelitian yang diperoleh pada tabel 5 bahwa dari 43 ibu bersalin dengan preeklampsia dengan riwayat preeklampsia sebanyak 6 orang $(14 \%)$.

Preeklampsia merupakan penyebab kematian ibu dan perinatal yang tinggi terutama dinegara berkembang. Kematian akibat preeklampsia meningkat lebih tajam dibandingkan pada tingkat preeklampsia berat. Oleh karena itu, menegakkan diagnosis preeklampsia merupakan tujuan pengobatan. Dikemukakan beberapa teori yang dapat menerangkan kejadian preeklampsia sehingga dapat menetapkan upaya promotif, dan preventif. Hasil penelitian Agung Supriandono dan Sulchan Sofoewanmenyebutkan bahwa terdapat $83 \quad(50,9 \%) \quad$ kasuspreeklapmsia mempunyai riwayat preeklapmsia, sedangkan padakelompok kontrol terdapat $12 \quad(7,3 \%)$ mempunyia riwayatpreeklampsia.

Berdasarkan penelitian di RS Aura Syifa Kabupaten Kediri bulan Februari - April tahun 2016 di temukan ibu yang mengalami preeklampsia dengan riwayat preeklampsia sebanyak 6 orang $(14 \%)$. Faktor risiko preeklampsia pada ibu yang mempunyai riwayat preeklampsia perlu di waspadai, karena ibu hamil dengan riwayat preeklampsia mempunyai resiko preeklampsia lagi, hal ini perlu di lakukan pengawasan lebih ketat pada ibu hamil karena sangat berbahaya jika ibu hamil mengalami preeklampsia bisa berdampak pada bayinya juga.

\section{Tidak ada faktor}

Dari hasil penelitian yang diperoleh dari tabel 5 bahwa dari 43 ibu bersalin dengan preeklampsia sebanyak $67 \%$.

Menurut teori ada beberapa faktor- faktor risiko terjadinya preeklamspsia yaitu paritas (primigravida dan grandemultigravida), usia, faktor lain meliputi (distansia rahim berlebihan (hidramnion, hamil ganda, molahidatidosa, janin besar), diabetus melitus, hipertensi kronis, riwayat preeklampsia serta tidak ada faktor preeklampsia).

Dari hasil penelitian yang dilakukan di RS Aura Syifa Kabupaten Kediri tahun 2016, di temukan terdapat sebanyak $67 \%$ orang preeklampsia yang tidak ada faktor risiko kejadian preeklampsia. Preeklampsia pada ibu bersalin harus mendapatkan pemantauan lebih intensif dengan cara melakukan ANC teratur pada ibu hamil. Dengan begitu preeklampsia dapat segera diatasi atau tindakan lebih lanjut serta mencari tahu faktor-faktor apa saja yang dapat mempengaruhi terjadinya preeklampsia pada ibu bersalin. Sehingga dapat mengurangi angka kejadian preeklampsia yang dapat menyebabkan kematian ibu dan bayi. 


\section{Simpulan}

Gambaran faktor-faktor risiko kejadian preeklampsia pada ibu bersalin dengan preeklampsia berdasarkan paritas tertinggi

\section{Daftar Pustaka}

Denantika O, Serudji J, Revilla Gusti Hubungan Status Gravida Ibu Terhadap Kejadian Preeklamsia di Fakultas Kedokteran Andalas Padang . Jurnal andalas. Vol 4 No. 1 Februari 2015 hal 212-213.

Hidayat, AAA. 2012. Riset Keperwatan Dan Teknik Penulisan Ilmiah. Jakarta : Salemba Medika.

JNPK-KR, 2008. Asuhan Persalinan Normal. Jakarta : Tim Revisi.

Lubis, NL, 2013. Psikologi Kespro Wanita Dan Perkembangan Reproduksinya. Jakarta : Kencana Perdana Media Group.

Manuaba, 2010. Ilmu Kebidanan, Penyakit Kandungan, Dan KB. Jakarta : EGC.

Marmi,et al. 2015. Asuhan Kebidanan Patologi. Yogyakarta : Pustaka Pelajar.

Notoatmodjo, S, 2010. Metodologi Penelitian Kesehatan. Jakarta : Rineka Cipta. 2012. Metodologi Penelitian Kesehatan. Jakarta : Rineka Cipta.

Nursal, Tamela, Fitrayeni Faktor Risiko Preeklampsia Pada Ibu Hamil Jurnal Kesehatan Masyarakat Andalas, Vol. 10, No. 1Oktober 2015 - Maret hal. 38-44.

Nursalam, 2013. Metode Penelitian Ilmu Keperawatan. Jakarta: Salemba Medika

Padila, 2014. Keperawatan Maternitas. Yogyakarta: Nuha Medika. 2015. Asuhan Keperawatan Maternitas II.Yogyakarta: Nuha Medika.

Purwaningsih, 2010. Asuhan Keperawatan Maternitas. Yogyakarta : Nuha Medika.

Pratiwi, CS, 2013.Faktor Resiko Ibu Hamil. Yogyakarta. Prodi DIII Kebidanan STIKES ‘ Aisyiyah.

Prawirohardjo,S,2009. Ilmu Kebidanan. Jakarta: PT Bina Pustaka Sarwono Prawirohardjo. ,2013. Ilmu kebidanan. Jakarta: PT Bina Pustaka Sarwono Prawirohardjo.

Radjamuda N, Montolalu A. Faktor-Faktor Risiko Yang Berhubungan Dengan Kejadian Hipertensi Pada Ibu Hamil Di Poli Klinik Obs- multigravida, usia tertinggi pada rentang 20-35 tahun, dan faktor lain karena distensia rahim berlebihan, hipertensi kronis serta riwayat preeklampsia.

Gin Rumah Sakit Jiwa Prof. Dr. V. L. Ratumbuysang Kota Manado. Jurnal Ilmiah Bidan. Vol. 2 No.1. Januari - Juni 2014.

Rakorpok Kementrian Kesehatan Ri, 2015. Kesehatan Dalam KerangkaSustainable Development Goals (SDGs). Jakarta.

Rukiah, A, et al. 2009. Asuhan Kebidanan II Persalinan. Jakarta: Trans Info Media.

Sabarguan, 2008. Karya Tulis Ilmiah Untuk Mahasiswa D3 Kebidanan. Jakarta : Anggota IKAPI.

Sastroasmoro,2008. Dasar-dasar metode penelitian klinis. Jakarta: CV Sugeng Sefa.

Sofian, A. 2013. Sinopsis Obstetri Jilid I. Jakarta EGC.

Sugiono,2012. Stastitika untuk penelitian. Bandung: Alfabeta.

Varney,H,2007. Buku Ajar Asuhan Kebidanan. Jakarta: EGC.

Wulandari, E, Wijayanti,2014. Jurnal Keperawatan, Vol 1, No.1.

Yogi ED , Haryanto, Sonbay E. Hubungan Antara Usia Dengan Preeklamsia Pada Ibu Hamil Di Poli KIA RSUD Kefamenanuka Kabupaten Timor Tengah Utara. Jurnal Delima Harapan, Vol 3, No.2 Agustus-Januari 2014 hal 10-19.

Noveliza.2012.Grandemultipara.https://midwif eryfonynoveliza.wordpress.com/2012/06/ 29/grandemultipara. [akses 22 Mei 2016].

Salwa.2016.Hubungan Diabetus Melitus Dengan Preeklampsia. http;//www.diabetics1.com/2016/03/hubu ngan-diabetes-dengan-preeklampsia. [Akses 18 Mei 2016].

Suwanti, Edi Prasetyo Wibowo, \& Nur Aini Safitri. (2012) Hubungan Tekanan Darah Dan Paritas Dengan Kejadian Preklampsia Di Ruang Bersalin RSUP NTB Tahun 2012. Media Bina Ilmiah . Volume 8, No. 1, Februari 2014. ISSN No. 1978-3787. Pp 25-30. 